\title{
NATOs udfordringer: Forsikre, afskrække og genetablere
}

Af Tage Baumann

Den aktuelle militære situation er præget af to forskellige usikkerheder. Mod øst en kendt og konstant modstander, en kendt trussel, en kendt konflikt men et ukendt handlemønster: en statisk ustabilitet. Mod syd en ukendt og stadigt skiftende modstandergruppering, en stadigt skiftende trussel og stadigt skiftende koalitioner: en dynamisk ustabilitet. NATOs udfordring er at finde fleksible, men konstante svar på de to ustabiliteter, både i form af afskrækkelse over for modstanderne og i form af forsikringer over for de NATO-lande, der grænser op til uroområderne.

Den 26. november 2015 forlangte NATOs generalsekretær Jens Stoltenberg i syv store europæiske aviser, at der bliver skrevet et nyt, moderne regelsæt for sikkerhed i Europa.

Det gjorde han fordi NATO-landet Tyrkiet få dage forinden havde skudt et russisk kampfly ned i grænseegnen mellem Tyrkiet og Syrien. Tyrkerne sagde, at flyet var i tyrkisk luftrum og offent- liggjorde en lydoptagelse, der angiveligt var den tyrkiske kamppilots advarsel til det russiske fly om at dreje af, før det krænkede tyrkisk luftrum. Rusland fastholder, at flyet blev skudt ned over syrisk område og henviser til, at navigatøren på det russiske kampfly reddede livet og landede i faldskærm på syrisk område. Piloten blev dræbt.

Flyet kom fra den russiske flyvestation i den nordlige Latakia-provins i Syrien og var en del af den militære oprustning i Syrien både i materiel og i militære handlinger, som præsident Vladimir Putin kort forinden, og til Vestens overraskelse, havde gennemført til støtte for den syriske præsident Bashar al-Assad. Eller måske for at sikre russiske interesser i den mellemøstlige storpolitik også $i$ en tid efter Assad.

Stoltenberg gjorde i sin minikronik i de syv aviser opmærksom på, at det sikkerhedsregime, der blev opbygget gennem årtier i organisationen for sikkerhed og samarbejde i Europa, OSCE, og som har virket længe efter den kolde krigs ophør, ikke længere magter udfor-

Tage Baumann er journalist på DR, Orientering. Hans primære stofområder er Tyskland og sikkerhedspolitik. 
Svenskerne diskuterer stadig med sig selv, om en russisk luftøvelse over Østersøen i virkeligheden var et gennemspillet angreb på militære anlæg i Sverige. Polakkerne er derimod ikke i tvivl: En af de større øvelser i det vestligste Rusland og i Hviderusland var, siger den polske regering, helt klart vendt mod mål i Polen.

dringen. Og at det tyrkisk-russiske problem er en brik i et meget større mønster, der omfatter krisen i og om Ukraine og de nye, aggressive sikkerhedspolitiske aktiviteter, som det russiske styre har lagt for dagen siden da. I form af militær opbygning i Ruslands vestlige og sydlige grænseområder, i nyformuleringer af russiske doktriner, der udpeger NATO som en trussel mod Rusland og Ruslands fjende, og $i$ en øvelsesaktivitet $i$ internationalt luft- og sørum, som med regelmæssige mellemrum har truet med at krænke andre landes suverænitet og tvunget europæiske lande til at afvise de russiske styrker, når de blev for nærgående.

Episoder som ofte nok har været faretruende nær på at løbe ud af kontrol. Og som ved en analyse af russernes øvelsesretning og øvelsesgenstand synes at gennemspille væbnede sammenstød med andre europæiske lande og på deres territorium.

Svenskerne diskuterer stadig med sig selv, om en russisk luftøvelse over Østersøen i virkeligheden var et gennemspillet angreb på militære anlæg i Sverige. Polakkerne er derimod ikke i tvivl: En af de større øvelser i det vestligste Rusland og i Hviderusland var, siger den polske regering, helt klart vendt mod mål i Polen. Dertil kommer så russiske advarsler til blandt andre Danmark om, at vi kan blive mål for russiske atomvåben, hvis vi vælger at bidrage til et amerikansk raketskjold.
Alt det her og mere til - for eksempel det der samles under begrebet hybridkrig - har skabt en stemning i Europa som i den kolde krigs heftigste dage, og det officielle NATO gør sig store anstrengelser for at forsikre om, at vi ikke står midt i en ny kold krig. En forsikring, Jens Stoltenberg gentog så sent som på den store årlige sikkerhedskonference i München i midten af februar.

\section{Statisk og dynamisk ustabilitet}

Militært set er situationen præget af to forskellige usikkerheder, sagde formanden for NATOs militærkomite, den tjekkiske general Petr Pavel på samme konference: Mod øst en kendt og konstant modstander, en kendt trussel, en kendt konflikt men et ukendt handlemønster: en statisk ustabilitet, kalder han det. Mod syd en ukendt og stadigt skiftende modstander-gruppering, en stadigt skiftende trussel og stadigt skiftende koalitioner: en dynamisk ustabilitet, med Pavels ord.

NATOs militære udfordring er at finde fleksible, men konstante svar på de to ustabiliteter, den statiske i øst og den dynamiske i syd. Både i form af afskrækkelse over for modstanderne og i form af forsikringer over for de NATO-lande, der grænser op til uroområderne. De baltiske og de østeuropæiske medlemmer i øst, i syd først og sidst Tyrkiet.

Det militære instrument til det er ved at tage form. Det er den hurtige udrykningsstyrke - NATO Response Force - 
som hele tiden har været der, men som først rigtig kom på sporet med Ukraineforskrækkelsen og de efterfølgende politiske beslutninger på topmødet i Wales for to år siden om at få styrken til at virke efter hensigten, at udvide den betydeligt - en fordobling til 60.000 mand - og at give den en særlig hurtig og slagkraftig 'spydspids'-styrke, som kan rykke ud med få timers, højst dages, varsel. Både mod øst og mod syd, som Jens Stoltenberg hele tiden minder om.

Det er imidlertid kun mod øst, i Baltikum, i Polen og i Rumænien, at NATO opbygger en række mindre hovedkvarterer, indretter fremskudte våbendepoter og holder betydelige NATO-styrker i en konstant ‘øvelses-rotation' for at forsikre Ruslands naboer blandt NATO-landene om alliancens solidaritet over for den trussel, som landene føler de er udsat for fra russisk side. Mod syd er indsatsen mere diffus og mindre i omfang. Udstationeringen af luftværnsraketter af typen Patriot i Tyrkiet, brugen af NATOs varslingsfly AWACS i tyrkisk luftrum og lidt mere afledt NATOs træningsindsats i det nordlige Irak for at styrke de kurdiske peshmerga-styrkers kampevner over for Islamisk Stat.

På det allerseneste må også NATOs søovervågning i Ægæerhavet for at spotte menneskesmuglere og overvåge flygtningestrømme mellem Tyrkiet og Grækenland regnes med, i hvert fald hvis man ser flygtningestrømmene fra Syrien som en sikkerhedstrussel mod NATO-området. Der er dem i NATO, der seriøst mener, at en del af Ruslands regnestykke er, at flygtningestrømmen kan skabe så store spændinger i sammenholdet i EU, at det europæiske projekt lammes eller bryder helt sammen, hvad der også ville være et hårdt slag mod NATO.

\section{NATO, EU og Rusland}

NATO og EU har brug for hinanden i lyset af disse nye udfordringer, og det er måske en af grundene til, at netop USA så kraftigt understreger, at Washington vil se et stærkt Storbritannien bevaret i et stærkt EU, som udenrigsminister John Kerry formulerede det i München.

EU kan ikke formulere et militært svar på nogen af de her udfordringer, heller ikke på terrorudfordringen, som det foreløbige efterspil på terrorangrebene i Paris i november har vist. Det svar skal ske i en koalition af villige og med støtte af NATO på den ene eller den anden måde. Omvendt kan NATO ikke svare militært på udfordringen fra Rusland i Ukraine, men må overlade det til EU sammen med USA at reagere med økonomiske sanktioner mod Rusland.

Problemet her for både EU og NATO er, at hverken forsøget på at styrke de nye frontlinjestater i øst eller forsøget på at tvinge Rusland til at ændre adfærd med økonomiske sanktioner virker. Og problemet er samtidig, at Europa og USA har brug for Rusland både i den fortsatte proces omkring det iranske atomprogram og i forhandlingerne først om en holdbar våbenhvile, så en eller anden form for fredsproces i Syrien og derefter det endelige opgør med Islamisk Stat i Syrien og Irak.

Eller sagt mere direkte: Vesten, og altså NATO, har brug for at tale med Rusland, og gøre det på samme tid som alliancen forsøger at forsikre de østeuropæiske frontlinjestater om alliancesolidaritet i lyset af den opfattede russiske trussel, og samtidig med at NATO satser på militær afskrækkelse med Moskva som adresse.

Det sidste blev nedfældet i vedtagelserne på topmødet i Newport i Wales for to 


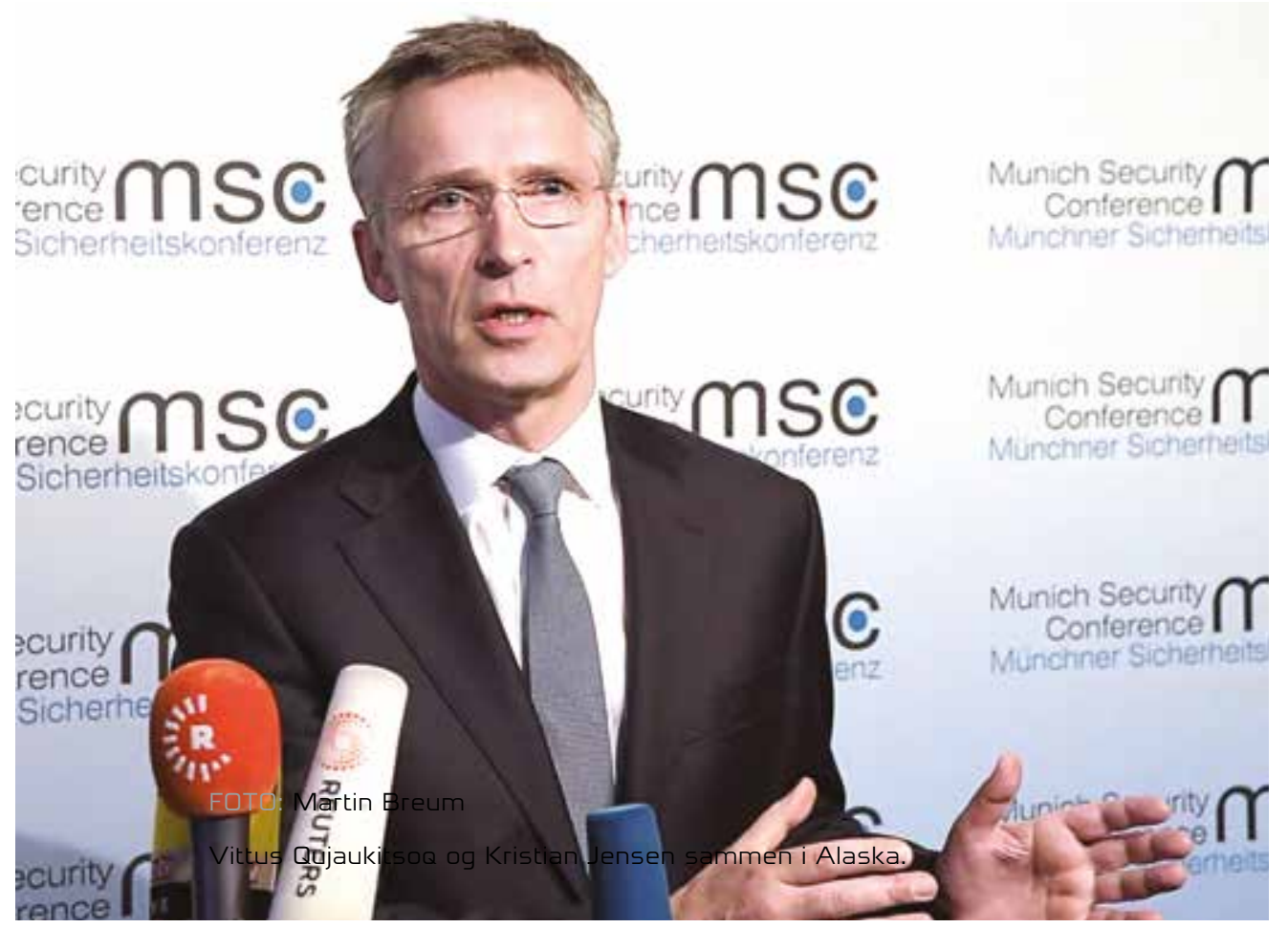

FOTO: NATO

NATOs generalsekretær, Jens Stoltenberg, på talerstolen på den store årlige sikkerhedskonference i München i midten af februar 2016.

år siden som en hensigtserklæring om, at NATO-landene igen vil stræbe efter at bruge to pct. af BNP på forsvaret. Foreløbig er det kun fem af NATOs 28 lande, der opfylder betingelsen. Danmark ligger aktuelt på knap 1,1 pct., og det ændrer sig ikke i det nuværende forsvarsforligs løbetid, det vil sige frem til udgangen af 2017. Så Danmark vil ikke kunne melde 'mission accomplished' på udgifterne på det kommende topmøde i Warszawa trods voksende amerikansk pres for at få de danske forsvarsudgifter op.

Man kan indvende, at forsvarsudgifter som del af BNP dybest set er vås og et mål, der kun bruges i mangel af bedre.
En stor stående styrke med mange værnepligtige, der ikke sendes på udlandsmissioner, kan være dyr uden at levere kampkraft. En mindre, men mobil og fleksibel styrke kan være billigere og alligevel levere mere kampkraft eller 'bang for the buck', som amerikanerne ynder at sige. En BNP-procent siger nok noget om det politiske ambitionsniveau, men ikke ret meget om de faktiske kampevner, som et land kan stille op med.

Bundlinjen i regnestykket siden den bratte opvågnen med Ukraine-krise og Krim-annekteringen i marts 2014 er imidlertid, at hverken afskrækkelse eller sanktioner har den ønskede effekt i Moskva, 
og at nødvendigheden af samarbejde i Mellemøst-sammenhæng trænger sig på. Derfor må NATO forsøge at nå ud over sin egen beslutning om at standse det praktiske samarbejde med Rusland i det særlige NATO-Rusland Råd. Hvordan det kan ske, kan ingen i dag sige.

\section{NATO-Rusland Rådet}

For nok hævder NATO stadig, at døren til politiske konsultationer i Rådet står åben, men for eksempel Polens nye regering gjorde det helt klart på sikkerhedskonferencen i München, at den ikke vil se nogen som helst beslutninger truffet $i$ NATO-Rusland Rådet. Et forsøg på at genetablere samtalen med Rusland kan ikke være en del af en løsning, sagde den polske udenrigsminister, for det vil give Rusland et veto i ting, som NATO skal beslutte selv. Vesten og Rusland skal ikke igen sidde og afgøre, hvordan vi andre skal leve, slog Witold Waszczykowski fast under debatten i det faste NATO-panel på konferencen.

Og mere end det. Waszczykowski sagde, at Polen overhovedet ikke anerkender hele den grundaftale, der oprettede NATO-Rusland Rådet. Det var før vi blev medlem af NATO, så det er vi ikke bundet af, sagde han. Og blev konkret: "Lad gå med, at man kan tale sammen i rådet. Men den del af grundaftalen (Founding Act), som siger, at NATO vil afstå fra at udstationere 'substantielle styrker' permanent i områder, der grænser op til Rusland, eksisterer ikke mere siden det russiske angreb på Ukraine, sagde han.

Og derfor kræver Polen nærmest ultimativt, at der nu stationeres NATO-styrker fast i Polen nær grænsen til Rusland. De polske synspunkter bakkes op af $\mathrm{Ru}$ - mænien og de baltiske lande, som mener, at de har brug for mere håndfaste garantier end de roterende NATO-styrker, der lige nu på skift er i de østeuropæiske lande. 'På øvelse' som det hedder.

Det er i sig selv på grænsen af aftalen med Rusland om NATO-Rusland Rådet, men kan lige præcis forsvares, lød det fra den tidligere NATO-generalsekretær Javier Solana i München. Det var Solana, der forhandlede grundaftalen med Rusland i 1997. Amerikanerne kommer østeuropæerne lidt i møde ved at sige, at læser man det, der er trykt med småt i aftalen, så kan det diskuteres, hvornår der er tale om 'substantielle styrker', og hvor meget NATO-infrastruktur der under aftalen kan opbygges i områder nær de russiske grænser.

Det her et et eksempel på de brudflader, de seneste to års dramatiske ændringer i det store sikkerhedspolitiske billede har skabt internt i NATO, og det viser, hvilke kraftanstrengelser, der skal til på det kommende topmøde i Warszawa i juli 2016 for at få en fælles forståelse af, hvordan NATO skal reagere på de nye rammebetingelser for fortsat at opfylde sin rolle som sikkerhedsgarant for alle NATO-lande.

I NATO under den kolde krig følte europæerne på et tidspunkt, at de var nødt til at samles i en 'euro-gruppe' for at hævde de særlige europæiske interesser og synsvinkler over for Washington. I slutningen af 2015 var det de østeuropæiske frontlinjestater, der mødtes i Bukarest i en slags 'Østeuropa-gruppe' for at formulere deres fælles interesser over for 'det gamle NATO'. Og der er meget lidt tvivl om, at de interesser ikke er fuldt ud forenelige med en samlet strategi, der kan gøre NATO i stand til 
at opfylde sine opgaver over for alle medlemslande.

Man kan sige det enkelt: en NATOsoldat, der er fast stationeret i Polen, er ikke til rådighed for et forsvar af Tyrkiet, hvis det er dér, truslen viser sig. Og et krigsskib, der er fast stationeret i Sortehavet, er ikke til rådighed for en indsats i Nordatlanten, hvis det er dér, der er behov for at stive NATOs suverænitetshåndhævelse af.

\section{Øget fokus på søstridskræfter}

Det var da også fra den norske statsminister Erna Solbjerg, at den polske udenrigsminister fik modspil i München. Svaret er ikke faste udstationeringer, svaret er fleksible og mobile styrker, sagde hun.

Også den diskussion kommer uden tvivl på topmødet i Warszawa.

Solbjerg åbnede så endnu en front i NATO-diskussionen ved at argumentere for, at Alliancen på topmødet i Warszawa igen ofrer mere opmærksomhed på søstridskræfterne. "Aldrig siden den kolde krig er vi blevet udfordret så meget til søs som i de seneste år. Fra Nordatlanten over Østersøen til Middelhavet og Sortehavet mærker vi udfordringen", sagde hun.

Norge forsøger at fastholde NATOs opmærksomhed på den sikkerhedspolitiske udvikling i Arktis og Nordatlanten, og det er mere end sandsynligt, at Norge kan få støtte til det perspektiv fra Danmark. Et øget dansk fokus på Arktis er et af kravene i den rapport, som ambassadør Peter Taksøe-Jensen i begyndelsen af maj fremlagde om et samlet nyt syn på Danmarks udenrigs-, sikkerheds-, forsvars- og udviklingspolitik.

Kravet om øget fokus på søværnet kommer også fra Rumænien, hvis præsident Klaus Iohannis i München forsøgte at få NATOs opmærksomhed henledt på den sikkerhedspolitiske situation i Sortehavet. Her er balancen er forskubbet i russisk retning efter den russiske annektering af Krim-halvøen, og NATO-lande med Sortehavskyster føler sig under stigende sikkerhedspolitisk pres fra Rusland.

Iohannis sagde i sit oplæg til paneldiskussionen om NATOs fremtidige udfordringer også, at han ikke ser nogen modsætning mellem NATOs behov for at bekræfte de østeuropæiske landes sikkerhed og behovet for at genetablere en sikkerhedspolitisk samtale med Rusland. Det handler i stedet om at finde den rette balance mellem de to, sagde han.

Lidt i modsætning til den polske udenrigsminister, som mellem linjerne fik sagt, at det er den forkerte vej at gå overhovedet at genetablere en sikkerhedspolitisk samtale med Rusland. Rusland, sagde han, opfatter konsultationer som noget, der skal ende med enighed om et ellert andet. For polakkerne betyder konsultationer med Rusland derimod udelukkende at informere russerne og ikke mere end det.

\section{Forud for Warszawa}

Ordstyrer for panelet var den amerikanske tidligere NATO-ambassadør og tidligere viceudenrigsminister for europæiske spørgsmål i State Department, Nicholas Burns. Han rejste tre kernespørgsmål, som også vil være dagsordenen for Warszawa-topmødet.

Det første er spørgsmålet om at styrke sikkerhedsgarantierne under NATOs musketered - artikel fem i pagten - til de baltiske lande og Polen i lyset af Ukraine. Det andet er spørgsmålet om, hvorvidt NATO-landene har de nødvendige mili- 
tære evner og kapaciteter, hver for sig og samlet, og hvordan det kan lykkes at få flertallet af medlemslandene op på at bruge to pct. af BNP på forsvaret fra 2018. Og det tredje er et centralt spørgsmål om NATOs ansvar over for partnerlandet Ukraine, og om NATO i sidste ende skal yde 'dødbringende våbenhjælp', som Burns sagde, til Ukraine, så det kan forsvare sit eget territorium.

Den britiske forsvarsminister Michael Fallon samenfattede de praktiske problemer for NATO op til topmødet i juli i tre punkter.

For det første må NATO indstille sig på at møde trusler fra enhver retning, ikke kun fra én enkelt kant. Der må udvikles en afskrækkelsesdoktrin, der er tilpasset det 21. århundredes nye og langt mere usikre tid, en doktrin, som ikke bare finder den rigtige balance mellem fremskudt tilstedeværelse og evnen til at forstærke i en fart, men som sikrer NATO-landene modstandskraft over for hybrid- og cyberkrig-angreb. Angrebsformer som udvisker skillelinjen mellem den militære og den civile dimension. For det andet må NATO blive bedre til at reagere hurtigt. Ikke bare med en spydspidsstyrke, men også med de rigtige og fleksible hjælpestrukturer og måske især med en hurtigere politisk beslutningsproces i Alliancen. Og for det tredje må det hele være ordentligt finansieret.

Også de tre punkter kommer topmødet til at arbejde med, for nok er noget sket i den retning, som Fallon her anbefaler, men der mangler stadig en del, før NATO har en omfattende strategisk afskrækkelsesevne, og der mangler stadig en del på finansieringen.

Storbritannien har sagt, at det vil bruge 2 pct. af BNP hvert år de kommende fem år, og også andre lande har meldt om nye store udgifter til forsvaret. Men ikke alt er, hvad det ser ud til.

Tysklands forsvarsminister, Ursula von der Leyen, har annonceret, at hun vil bruge omregnet næsten 1.000 milliarder kroner ekstra på forsvaret de kommende 15 år. Det kunne lyde som en væsentlig oprustning, men i det kæmpebeløb gemmer sig helt nødvendige udgifter til erstatning af helt basalt udstyr, som tyskerne har slidt ned og forsømt at vedligeholde de seneste mange år. Ikke kun større våbensystemer, køretøjer og kommunikationsudstyr, men også soldaters personlige udstyr som natbriller, skudsikre veste og den slags fundamentale ting. Og så skal mange tyske kaserner renoveres, fordi de er blevet forsømt i lang tid, mens pengene er gået til blandt andet den tyske styrke i Afghanistan.

Så mange af de ekstra penge går til bare at opretholde omtrent den kampkraft, tyskerne har i øjeblikket, selv om der også i det her program er en reel oprustning og modernisering. Men læren er, at ikke alle udmeldinger om øgede forsvarsudgifter kan omsættes direkte til øget kampkraft. Og så skal det da lige tilføjes, at forsvarsministeren i Berlin endnu ikke har fået finansministerens ja til den ambitiøse udgiftsplan. Et problem for topmødet i Warszawa bliver netop at skille de politiske udmeldinger og de reelle tilførsler af militære evner til den samlede alliance nøgternt fra hinanden.

Der er ikke kun behov for flere penge, men også for at genoprette nogle af de evner, der de seneste ti-femten år er blevet ofret for at udvikle hurtigt deployerbare styrker over store afstande, det 'indsatsforsvar' som Danmark besluttede sig for at lade afløse tidligere tiders territorial- 
forsvar for at kunne påtage sig operationer som den i Irak og i Afghanistan. Tyskland gik i samme retning, men har tænkt om og satser nu igen - i lyset af Ukraine - på for eksempel tunge kampvognsbaserede enheder, der mere hører hjemme i territorial- eller områdeforsvarets værktøjskasse end i indsatsforsvaret.

Danmark har trods de nye udfordringer i nærområdet efter Ukraine ikke tænkt sig at se tilbage, men vil fortsat s atse på et indsatsforsvar. Det gjorde forsvarsminister Peter Christensen klart for nylig i en tale i Det Krigsvidenskabelige Selskab.

Om topmødet vil vælge at gå videre med generalsekretær Jens Stoltenbergs ønske om et nyt sæt regler for, hvordan NATO og Rusland i den nye sikkerhedspolitiske situation undgår sådanne farlige mellemspil som den russisk-tyrkiske flyepisode i grænseområdet til Syrien, undgår at fejlfortolke hinandens handlinger eller hensigter og undgår, at sikkerheden går tabt, fordi enkeltepisoder eskalerer ud af kontrol, står endnu uvist hen.

\section{Et 'Memorandum of Understanding'}

Lederen af den sikkerhedspolitiske tænketank European Leadership Network (ELN), Ian Kearns, mener, at der er alvorligt brug for en ny forståelse, et 'Memorandum of Understanding', mellem NATO og Rusland for at kunne håndtere den slags farlige mellemspil.

Sådan en aftale findes ikke mellem NATO og Rusland i dag, skriver han, selv om der findes enkelte bilaterale aftaler mellem Rusland og individuelle NATO-lande. ELN har opgjort, at der fra marts 2014 til marts 2015 var 60 sådanne farlige situationer til søs og i luften i det euro-atlantiske område. $\mathrm{Og}$ senest den tyrkisk-russiske episode med det nedskudte fly har ifølge Kearns på dramatisk vis demonstreret behovet for at få sådan en aftale med Rusland. Også det kan blive en af udfordringerne på Warszawa-topmødet.

Og så kan topmødet i øvrigt få vanskeligt ved at beslutte ret meget, fordi det kommer, netop som den amerikanske præsidentvalgkamp nærmer sig sin varme slutfase. Og nok kan præsident Barack Obama indgå aftaler i Warszawa, men han skal have den amerikanske kongres med sig, og den er alt andet end enig med manden i Det Hvide Hus. Resultatet kan blive, at USA's politiske manøvremulighed er stærkt begrænset på topmødet, og så kan mødet ikke bevæge ret meget i og for alliancen. Uanset hvor store udfordringerne er.

Med generalsekretær Jens Stoltenbergs ord så er det, vi ser nu, ganske vist ikke en ny kold krig. Men det er en øjenåbner. 